\title{
Noise from power generators: it's impact on the health of five children below two years of age
}

\author{
Manouri P Senanayake ${ }^{1}$ \\ Sri Lanka Journal of Child Health, 2002; 31: 115-7
}

(Key words: noise pollution, children)

\section{Introduction}

Excess noise harms health. The third most serious environmental issue in the world, after air and water pollution, is noise pollution. Common sources of community noise are construction sites, industrial machinery, urban traffic, military activities and loud music. The effects of noise are auditory and nonauditory and children are more vulnerable than adults to high intensity noise $e^{1,2,3,4}$. The health of five children exposed to excessive noise produced from power generators is reported.

\section{Objective}

To study the health effects of a cohort of children exposed to chronic and excessive noise.

\section{Study population}

The ages of the five children studied ranged from $31 / 2$ months to 2 years. They were unrelated, had no prior medical or developmental problems and lived in a residential area in the suburbs of Colombo described in the national statute as a "medium noise zone". These children were being exposed to a loud noise for 24 hours each day, for over three months.

\section{Environmental disturbance}

A power plant located close to the homes of these children created excessive noise due to the 24-hour operation of eight diesel generators. Adult residents in the area complained of lack of sleep and speech unintelligibility within their homes. Noise level measurements were carried out outside these homes by the Central Environmental Laboratory, Colombo conforming to standards stipulated by the International Electrochemical Commission. The noise levels recorded ranged from 73 to 78 decibels during daytime and 70 to 73 decibels at night.

\footnotetext{
${ }^{1}$ Senior Lecturer in Paediatrics, University of Colombo.
}

(Received on 27 September 2002)

\author{
Study setting \\ University Child Development Clinic, Lady \\ Ridgeway Children's Hospital Colombo.
}

\section{Method}

Behavioural changes were assessed by history-taking and observation. Clinical examination included hearing assessment by clinical and audiometric testing, growth assessment using Tanner Whitehouse standards and development scoring with Griffith Developmental Scales. Random blood pressures were recorded when awake by the auscultatory technique using appropriate cuffs and compared with reference standards of the American Academy of PaediatricsTask Force on Blood Pressure.

\section{Results}

Sleep disturbance was present in all five children. "Pulling at the ear", irritability and tiredness were described in four children. A hearing loss over a wide range of frequencies was found in one child with no identifiable genetic or medical cause to account for it. Another child had hypertension for which no underlying renal, cardiac or endocrine cause was found. A persistent diarrhoea which had begun after the onset of the noise was present in one child but no infective or metabolic cause was revealed on investigation. These children were too young for the assessment of reading abilities and performance of complex tasks. Details of clinical findings are shown in Table 1 . 
Table 1

Clinical findings of children exposed to excessive noise

\begin{tabular}{|c|c|c|c|c|c|c|c|c|c|c|c|}
\hline Patient & $\begin{array}{l}\text { Age in } \\
\text { months }\end{array}$ & $\operatorname{Sex}$ & $\begin{array}{c}\text { Sleep } \\
\text { disturbance }\end{array}$ & $\begin{array}{c}\text { Behaviour } \\
\text { changes }\end{array}$ & $\begin{array}{c}\text { Motor } \\
\text { development }\end{array}$ & Speech & $\begin{array}{l}\text { Heart } \\
\text { rate }\end{array}$ & $\begin{array}{c}B P(\text { centile }) \\
\text { sys/diast }\end{array}$ & $\begin{array}{l}\text { Acoustic } \\
\text { symptoms }\end{array}$ & Hearing & $\begin{array}{c}\text { Other } \\
\text { symptoms }\end{array}$ \\
\hline I & $31 / 2$ & $\mathrm{M}$ & $\begin{array}{l}\text { Day \& } \\
\text { night } \\
\text { waking } \\
\text { with a start }\end{array}$ & $\begin{array}{l}\text { Difficult } \\
\text { to console }\end{array}$ & Normal & $\begin{array}{c}\text { Not } \\
\text { vocalising }\end{array}$ & 106 & $\begin{array}{l}75^{\text {th }}-90^{\text {th }} \\
75 \text { th }-90^{\text {th }}\end{array}$ & - & Normal & - \\
\hline II & 10 & M & $\begin{array}{l}\text { Lack of } \\
\text { sleep }\end{array}$ & Irritable & Normal & $\begin{array}{c}\text { Not } \\
\text { babbling }\end{array}$ & 100 & $\begin{array}{l}<50^{\text {th }} \\
<50^{\text {th }}\end{array}$ & - & Normal & - \\
\hline III & 12 & $\mathrm{~F}$ & Night time & Fretful & Normal & Delayed & 105 & $\begin{array}{l}>90^{\text {th }} \\
>90^{\text {th }}\end{array}$ & - & Abnormal & \\
\hline IV & 14 & $\mathrm{~F}$ & $\begin{array}{l}\text { Altered } \\
\text { sleep }\end{array}$ & Irritable & Normal & Normal & 90 & $\begin{array}{l}<50^{\text {th }} \\
<50^{\text {th }}\end{array}$ & $\begin{array}{l}\text { "pulling } \\
\text { at ears" }\end{array}$ & Normal & $\begin{array}{c}\text { Persistent } \\
\text { non } \\
\text { infective } \\
\text { diarrhoea }\end{array}$ \\
\hline V & 24 & M & Difficult to & "Tired" & Normal & Normal & 90 & $\begin{array}{c}<50 \text { th } \\
50 \text { th-75th }\end{array}$ & - & Normal & - \\
\hline
\end{tabular}

\section{Discussion}

Deleterious health effects due to excessive noise affect different persons differently. They include audiological damage, psychological symptoms and physiological alterations. The best known of these is sensory neuronal deafness, which is caused by reversible damage to hair cells of the organ of Corti and destruction of dendrites of the primary auditory neurons ${ }^{6}$.

In chronically noise-exposed children, damage to hearing begins as a temporary threshold shift with a hearing loss up to 60 decibels. In the absence of auditory rest, synaptic repair mechanisms do not take place and permanent hearing loss sets in involving all frequencies. It takes two to 25 days for the temporary threshold shift to become permanent. One child in our study had a hearing loss which was probably induced by noise.

High frequency tinnitus is also reported to follow acoustic trauma. The five children studied were too young to complain of ringing / buzzing sounds in their ears but lack of sleep, irritability, "pulling at ears", "headache" and "tiredness" were detected.

Disturbance of sleep is believed to occur when bedroom noise levels exceed 35 decibels $^{7}$. Difficulties in falling asleep, being woken from sleep and altered sleep patterns were common findings in our study.

The literature on behavioural changes states that adverse environmental characteristics, such as overcrowding and poor housing, often co-exist making it difficult to determine noise exposure as a causative factor of behaviour abnormalities. However, language acquisition and reading are known to be affected by noise ${ }^{8}$. Poor pupil performance as a result of noise around schools is well documented ${ }^{9}$.

Laboratory and field studies on animals and humans exposed to noise demonstrate a statistically significant elevation of blood pressure ${ }^{10,11}$. This risk is greater in children. One of the children in our series was found to have hypertension with no identifiable renal, cardiac or endocrine cause. Another child had gastrointestinal symptoms compatible with alterations in physiological mechanisms of stress reactions. Increased secretion of hormones indicative of sympathetic nervous system overactivity explains these effects -i.e. increased blood pressure and increased intestinal hurry.

The universally accepted nuisance level of noise is $60 \mathrm{~dB}$. Noise levels recorded near the homes of these children exceeded the statutory noise standards applicable to their area of residence (63 $\mathrm{dB}$ during daytime, $50 \mathrm{~dB}$ at night).

In conclusion, the five children studied had effects of excessive noise exposure. The purpose of this paper is to draw the attention of paediatricians to the effects of noise on young children and to highlight the need for strictly policed environmental noise standards. Children need protection from auditory and non- auditory harm caused by noise.

P.S. A case filed by the Public Interest Law Foundation in the names of these children was 
upheld by court, with order for immediate cessation of the noise and payment of compensation to each of the five minor petitioners.

Noise induced hearing loss is the largest single 'compensatable illness' in the world ${ }^{12}$.

\section{Acknowledgements}

I thank Mr. Lalanath de Silva, President Public Interest Law Foundation, Colombo, for referring these children and obtaining noise level measurements; and Prof. Gary W Evans, College of Human Ecology, Cornell University, New York USA. for help in interpreting the findings.

\section{References}

1. Borsky P N. Research on community response to noise since 1973. Proceedings of the 3rd International Congress on Noise as a Public Health Problem.1980: Ed: JR Tobias. American Speech and Hearing Association.

2. Cohen S, Krantz O S, Evans G W, Stokols D. Cardiovascular and behavioural effects of community noise. American Scientist 1981; 69(5): 528-35.

3. Heft H. Background and focal environmental conditions of the home and attention in young children. Journal of Applied Social Psychology1979; 9: 47-9.

4. Glorig A. Non-auditory effects of noise exposure. Sound and vibration 1971; 5: 28-9.
5. Gazette Extraordinary of the Democratic Social Republic of Sri Lanka. 924/12, 23.5.1996 part I section.13A-4A.

6. Briste S K, Hensen D A, Strand R L. Hearing loss among high school students. American Journal of Public Health 1989; 79: 619-72.

7. Physiological effects of intense noise. In: Noise and Health 1986. Ed: Loed M.

8. Lane S R, Meechara W C. Jet noise at schools near Los Angeles International Airport. Journal of Acoustical Society of America 1974; 56: 127-31.

9. Sanz S A, Garcia A M, Garcia A. Road traffic noise around schools: a risk for pupils' performance? International Archives of Occupational and Environmental Health 1997; 65(3): 205-7.

10. Regecova V. Kellerova E. Effects of urban noise pollution on blood pressure and heart rate in preschool children. Journal of Hypertension 1995; 13(4): 405-12.

11. Peterson E A, Augestein D C. Noise raises blood pressure without impairing auditory sensitivity. Science 1981; 211: 1450-2.

12. Abdulla S. Cochlear pharmacology and noise trauma: prevention and progress. Bulletin 1998; 50: 16-7. 